\title{
Recent research trends in organic Rankine cycle technology: A bibliometric approach
}

Imran, Muhammad; Haglind, Fredrik; Asim, Muhammad; Zeb Alvi, Jahan

\section{Published in:}

Renewable and Sustainable Energy Reviews

Link to article, DOI:

10.1016/j.rser.2017.08.028

Publication date:

2018

Document Version

Peer reviewed version

Link back to DTU Orbit

Citation $(A P A)$ :

Imran, M., Haglind, F., Asim, M., \& Zeb Alvi, J. (2018). Recent research trends in organic Rankine cycle technology: A bibliometric approach. Renewable and Sustainable Energy Reviews, 81, 552-562.

https://doi.org/10.1016/j.rser.2017.08.028

\section{General rights}

Copyright and moral rights for the publications made accessible in the public portal are retained by the authors and/or other copyright owners and it is a condition of accessing publications that users recognise and abide by the legal requirements associated with these rights.

- Users may download and print one copy of any publication from the public portal for the purpose of private study or research.

- You may not further distribute the material or use it for any profit-making activity or commercial gain

- You may freely distribute the URL identifying the publication in the public portal 


\section{Recent research trends in organic Rankine cycle technology: A bibliometric approach}

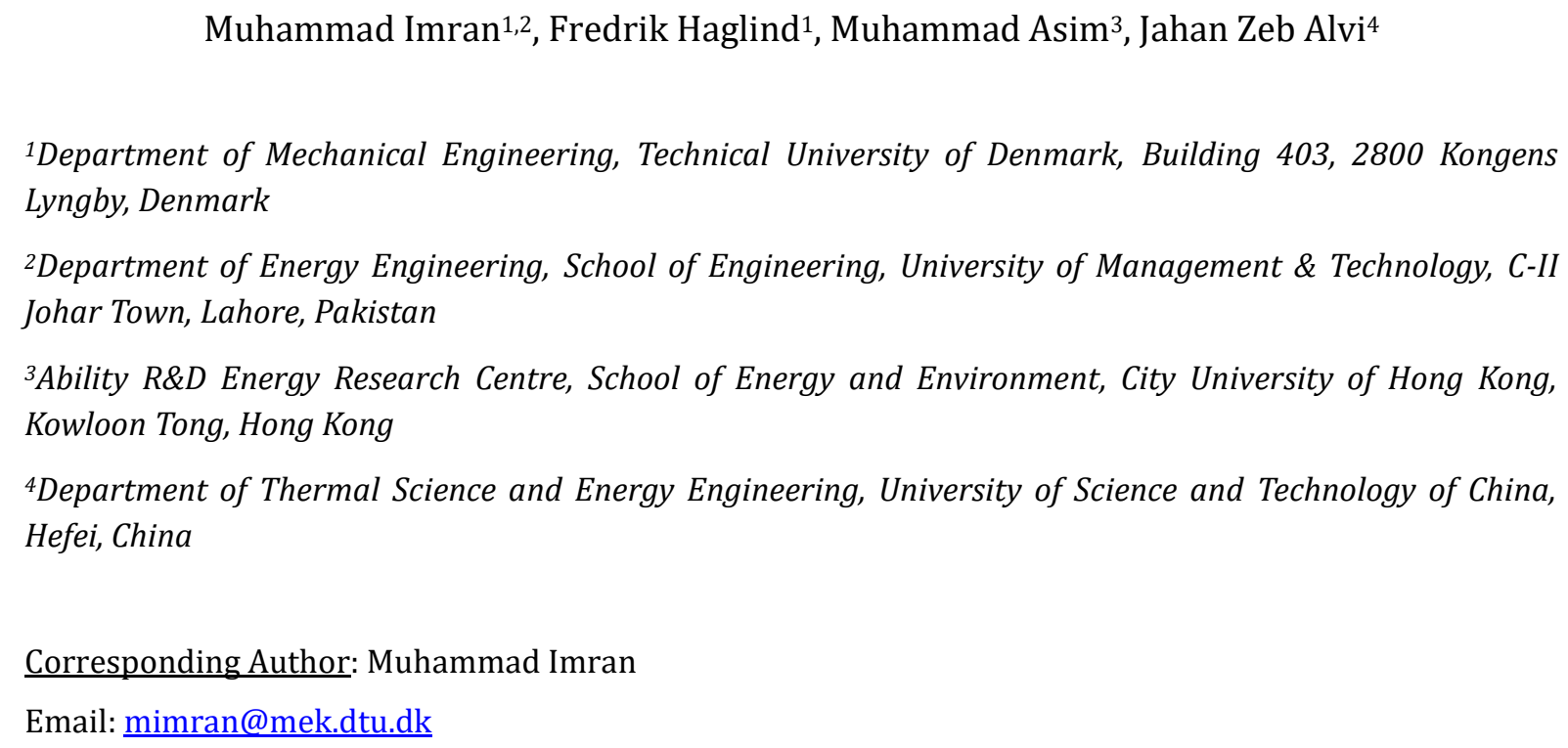


This work describes the contribution of researchers around the world in the field of the organic Rankine cycle in the period 2000-2016. A bibliometric approach was applied to analyze the scientific publications in the field using the Scopus Elsevier database, together with Science Citation Index Expanded. Different aspects of the publications were analyzed, such as publication type, major research areas, journals, citations, authorship pattern, affiliations as well as the keyword occurrence frequency. The impact factor, h-index and number of citations were used to investigate the strength of active countries, institutes, authors, and journals in the organic Rankine cycle technology field. From 2000 to 2016, there were 2120 articles published by 3443 authors from 997 research institutes scattered over 71 countries. The total number of citations and impact factor are 36739 and 4597, respectively, corresponding to 17 citations per paper and an impact factor of 2.168 per publication. The research articles originate primarily from China, the USA, and European countries. Results indicate that China, the United States, Italy, Greece, Belgium, Spain, Germany and the United Kingdom are the leading countries in organic Rankine cycle research and account for $64 \%$ of the total number of publications. The core research activities in the field are mainly focused on applications of the organic Rankine cycle technology, working fluids selection/performance, cycle architecture, and design/optimization. The most productive journal, author, institution, and country are Energy, Ibrahim Dincer, Tianjin University China and China, respectively.

Keywords: Organic Rankine Cycle, Scientometric, Bibliometric, Research trends, Low temperature, Waste heat

\section{Introduction}

In the last two decades, the growing concern over energy efficiency, finite fossil fuel resources and their environmental impact has accelerated the research work in the field of clean and efficient energy technologies [1]. Efficient conversion of low temperature heat and waste heat into power can effectively reduce the greenhouse gas emission and significantly improve energy efficiency of energy systems [2]. However, conventional energy conversion technologies are not suitable for efficient conversion of low temperature heat sources [3]. The Organic Rankine Cycle (ORC) technology is considered viable technology, being progressively adopted as the premier technology for efficient conversion of low temperature heat into power [4].

Extensive research activities have been observed in ORC technology from 2000 onwards due to the increased attention to low-to-medium temperature heat recovery. The adoptability to various heat sources, low complexity, automated control and distributed power generation ability make the ORC technology an ideal choice for power production from low temperature heat and waste heat [5]. Potential applications of the ORC technology include biomass, solar, geothermal, ocean thermal energy and waste heat recovery from various thermal processes [6]. It appears that future regulations will focus more on $\mathrm{CO} 2$ emissions and energy efficiency, thus providing ample chances of further research and development in the ORC field.

A number of review articles have been published in the past covering different aspects of the ORC technology. Lion et al. [7], Sprouse III and Depcik [8], and Saidur et al. [9] reviewed the use of ORC power systems for waste heat recovery from internal combustion engines. 
1 Tocci et al. [10] and Rahbar et al. [11] investigated the small-scale applications of ORC power 2 systems. Regarding working fluids for ORC units, Bao and Zhao [12] and Chen et al. [13] 3 provided a comprehensive review and selection criteria of pure working fluids. Modi and 4 Haglind [14] and Abad and Kim [15] investigated the potential and challenges of the use of 5 zeotropic mixtures for ORC applications. Later, Dai et al. [16] analyzed the thermal stability of 6 the working fluids. As for component level reviews, Imran et al. [17], Song et al.[18], and Bao et 7 al. [12] provided comprehensive reviews of selection and performance of expanders for ORC 8 power systems. Lecompte et al. [19] presented a generalized overview of cycle configurations 9 and cycle architectures, and Zhai et al. [20] investigated the potential heat sources and 10 categorized them for ORC applications.

11 With the advancement of ORC technology, the literature related to the ORC field has grown substantially. Therefore, it is of crucial importance to identify the core research themes, contribution of authors and institutes in the ORC field, and qualitatively assess the ORC publications. None of the previous review works on the ORC technology addresses these aspects. Moreover, there has been a significant increase in quantitative evaluation of the literature using scientometric and bibliometric approaches in recent years.

A number of studies have been conducted in this regard to assess and evaluate the research activities in a certain field. A list of scientometric and bibliometric studies in the field of energy is shown in Table 1.

Table 1: Scientometric and bibliometric studies in the field of energy

\begin{tabular}{llc}
\hline Ref. & \multicolumn{1}{c}{ Description } & $\begin{array}{c}\text { Literature } \\
\text { timeframe }\end{array}$ \\
\hline$[21]$ & Research output and priorities in renewable energy & $1996-1999$ \\
{$[22]$} & Emerging technologies in the energy research field & $1970-2005$ \\
{$[23]$} & Hydrogen energy research and literature review & $1965-2005$ \\
{$[24]$} & Evaluation of research on algae and bio-energy & $1980-2010$ \\
{$[25]$} & Scientometric profile of solar energy research in India & $1999-2011$ \\
{$[26]$} & Research profile of production of Bioenergy from biomass & $1980-2011$ \\
{$[27]$} & Mapping organic farming and Bioenergy research work & $1980-2012$ \\
{$[28]$} & International collaboration in wind/ solar energy & $1998-2010$ \\
{$[29]$} & Recent advances in energy efficiency research & $1990-2010$ \\
{$[30]$} & Research trends in energy in Spain & $1957-2012$ \\
{$[31]$} & Recent solar energy literatures & $1990-2011$ \\
{$[32]$} & Alternative energy research profile and research output & $1994-2013$ \\
{$[33]$} & Past, present and future of biomass energy research & $1990-2011$ \\
{$[34]$} & Energy management strategies for hybrid electric vehicles & $1998-2014$ \\
{$[35]$} & Analysis of energy poverty research on a global scale & $1981-2013$ \\
{$[36]$} & Evaluation of research on multi-energy systems & $1996-2015$ \\
{$[37]$} & Energy-related issues in green supply chain management & $1995-2012$ \\
{$[38]$} & Scientometric global synthesis and challenges of microbial fuel cells & $1985-2015$ \\
{$[39]$} & Chinese energy and fuels research priorities & $1993-2012$ \\
{$[40]$} & Characteristics and research trends of waste-to-energy incineration & $1999-2015$ \\
{$[41]$} & Research trends of low-carbon energy technology investment & $1981-2015$ \\
{$[42]$} & Modeling-based bibliometric exploration of hydropower research & $1994-2013$ \\
\hline
\end{tabular}


The primary objective of this study is to evaluate quantitatively and qualitatively the global trend of research activities within the ORC field, considering scientific papers published in the period from 2000 to 2016.

The publication statistics, geographical distribution of authors and institutions, list of authors, institutions and journals with significant contribution in the field of ORC technology, citations and authorship pattern are investigated in the present study. Effective performance parameters are selected for the comparative evaluation of the contribution of authors, institutions, and countries. This is the first review paper on ORC technology taking a bibliometric approach, and by providing a very useful overview for researchers active in the field, it may influence researchers' future research directions.

The paper is divided into four sections. The research methods are briefly explained in section 2 , while section 3 covers the results and discussion. Finally, a few concluding remarks are outlined in section 4.

\section{Methods}

A complete search in the Scopus database was carried out using the words "organic Rankine cycle" in the search bar in "article title, abstract, and keywords", considering the period 20002016. The search results were further filtered using the language "English" and document type as "article and conference proceedings". Finally, the complete data of 2124 documents whose topics (titles, keywords and abstracts) contain the word "organic Rankine cycle" and 4221 patents in the ORC field were obtained. The results were further filtered to remove irrelevant and incomplete data. Finally, the refined data consisting of 2120 articles and 3472 patents were considered for the scientometric study of the ORC technology.

\subsection{Research output indicators}

Impact factor, h-index, and source normalized impact factor were chosen to analyze the influence of the journals, authors, institutions and countries. The quality of modern research is measured on the basis of impact factor; the impact factor of a journal in the nth year is the number of citations in nth year divided by the number of publications in the same year. The impact factor was introduced by the Institute for Scientific Information (ISI) and is indexed in the Journal Citation Reports (JCR) yearly. The h-index measures both the productivity and citation impact of the publications. The h-index is $\mathrm{N}$ if $\mathrm{N}$ publications, each of which has been cited in other papers at least $\mathrm{N}$ times. The source normalized impact factor measures contextual citation impact by weighting citations based on the total number of citations in a subject field. In the present study, the impact factor of a given journal was determined as reported in the 2016 Journal Citation Report.

In order to measure the qualitative research output at the institution and country level, a number of research indicators have been used. These research indicators include the i-10 index, productive authors, productive institution, and hot articles. The i-10 index is the number of publications having more than 10 citations. The authors and institutions having more than five publications are termed as productive authors and institutions, respectively. Articles with more than 50 citations are entitled hot articles. For comparative assessment of research output, the impact factor per publication (IFPP) and citation per publication (CPP) were also used. 


\section{$1 \quad 2.2 \quad$ Collaboration degree}

2 Three indicators were chosen to investigate the effect of research collaboration. These factors 3 are the auctorial collaboration degree, institutional collaboration degree, and national

4 collaboration degree and can be represented as

$D_{a}=\frac{\sum_{i=1}^{n} \alpha_{i}}{N}$

$D_{i}=\frac{\sum_{i=1}^{n} \beta_{i}}{N}$

$D_{n}=\frac{\sum_{i=1}^{n} \gamma_{i}}{N}$

$5 D_{a}, D_{i}, D_{n}$ are the auctorial collaboration degree, institutional collaboration degree, and national 6 collaboration degree, respectively, and $\alpha_{i}, \beta_{i}$, and $\gamma_{i}$ are the number of the authors, countries, 7 and institutions for each paper. The parameter $N$ represents the total number of papers. It 8 needs to be noted that the number of countries is the sum of all authors' countries, and similarly 9 the number of institutions is the sum of institutions of all the authors.

\section{$2.3 \quad$ Research output indicators}

In order to analyze the qualitative research output at the institute and country levels, a comprehensive approach was adopted. Eight research output indicators were chosen, namely, the number of publications, number of citations, h-index, cumulative impact factor ${ }^{1}$, number of productive authors ${ }^{2}$, number of productive institutions ${ }^{3}$, number of hot articles ${ }^{4}$, and the number of citations of hot articles. These indicators were used to calculate the standard research score of each country:

$S_{p q}=\frac{x_{p q}-\bar{x}_{q}}{\bar{x}_{q}}+1$

where $S_{p q}$ is the standard research score of indicator q in country $p, x_{p q}$ is the original score of indicator $q$ in country $p$, and $\bar{x}_{q}$ is the average score of indicator $q$. The sum of all standard research scores of a country is

$S_{p}=\sum_{q=1}^{8} S_{p q}$

where $S_{p}$ is the cumulative research output score of country $p$, and $q$ is the research output indicator. There are eight research indicators used in the present study.

\footnotetext{
${ }^{1}$ Sum of impact factors of all the publications from 2000 to 2016 in the ORC technology field.

${ }^{2}$ Authors who have published more than four research articles in the ORC technology field.

${ }^{3}$ Institutions which have more than four research articles in the ORC technology field.

${ }^{4}$ Articles that have more than 50 citations.
} 


\section{$13 . \quad$ Results and discussion}

\subsection{General statistics}

From 2000 to 2016, the total number of publications amounts to 2120 in the Scopus indexed journals and conference proceedings. The timeline of ORC publications from 2000 to 2016 is shown in Figure 1. The research publications and the patents have overall increasing trends from 2000 to 2015; however, a very slight decrease in publications and patents is observed in the year 2016.

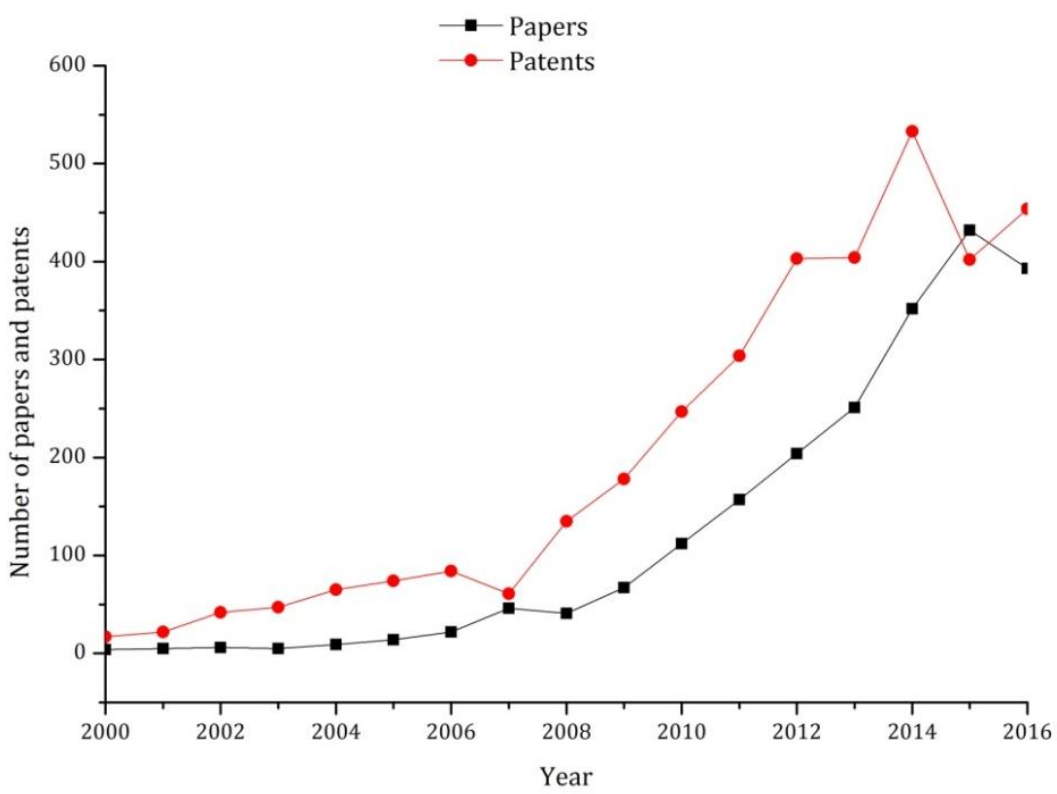

Figure 1: Timeline of publications and patents from 2000-2016

The rapid increase in publications from 2008 onwards may, among other things, be attributed to the growing concerns of the environmental impact and need for efficiency improvement of energy systems. An analysis of the type of publications suggests that the "Original articles" account for the largest share of the publications, about $61.84 \%$ of the published papers as shown in Figure 2.
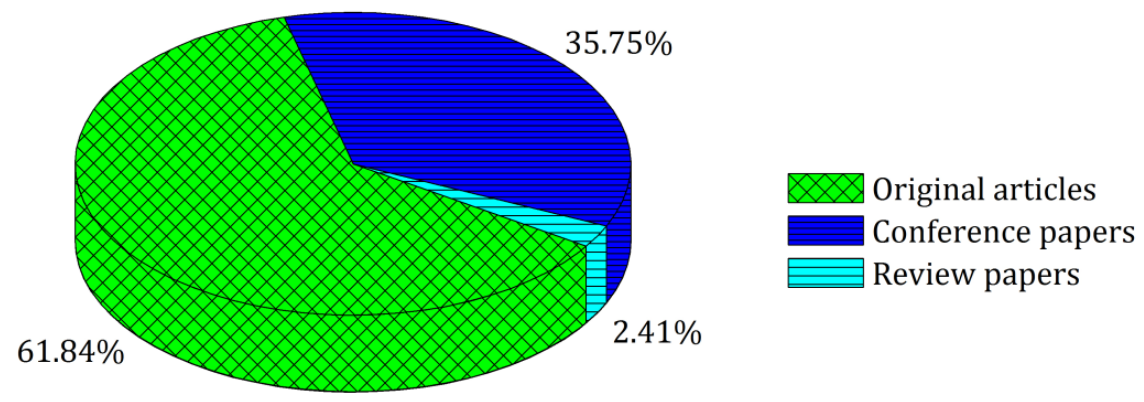

Figure 2: Types of publications within the ORC technology field from 2000 to 2016

\subsection{Country statistics}

The published articles originate from over 71 countries as shown in Figure 3. However, it can be observed that the largest share of publications originates from only a few countries. 


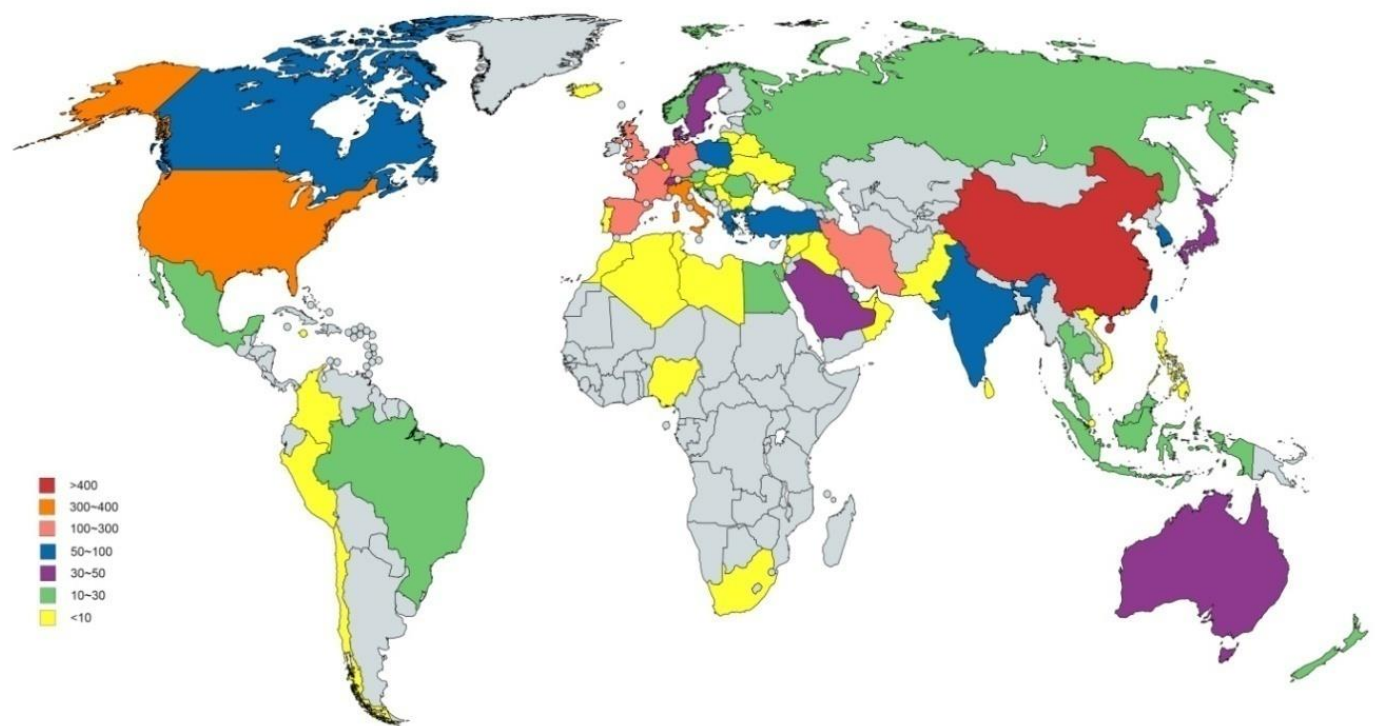

Figure 3: Geographical distribution of publications in the ORC technology field

The most productive countries on the basis of number of publications are listed in Table 2 . About $83.7 \%$ of the publications are from the top 20 countries shown in Table 2. In the statistical analysis, if a publication has more than one author from each country, the publication was considered for both countries. The ORC publications originate primarily from China, the USA, and Europe (Italy, Germany, Spain, Poland, Belgium, and France), with China being the leading country representing $17.3 \%$ of the total number of ORC publications from 2000 to 2016.

\begin{tabular}{|c|c|c|c|c|c|c|c|c|}
\hline \multirow{2}{*}{ Country } & \multicolumn{2}{|c|}{ Total } & \multicolumn{2}{|c|}{ Number of productive } & \multicolumn{2}{|c|}{ Hot articles } & \multicolumn{2}{|c|}{ Quality } \\
\hline & Articles & Citations & Authors & Institutions & No. & Citations & Total IF & h-index \\
\hline China & 440 & 7562 & 55 & 22 & 37 & 4162 & 1227.58 & 44 \\
\hline United States & 297 & 4930 & 36 & 15 & 21 & 3147 & 415.302 & 32 \\
\hline Italy & 286 & 4006 & 39 & 23 & 17 & 1568 & 549.124 & 33 \\
\hline Germany & 145 & 2312 & 17 & 11 & 9 & 1557 & 228.241 & 19 \\
\hline United Kingdom & 130 & 1510 & 20 & 7 & 7 & 576 & 311.022 & 22 \\
\hline Belgium & 81 & 2335 & 10 & 5 & 11 & 1818 & 172.49 & 18 \\
\hline Iran & 76 & 1000 & 6 & 8 & 3 & 252 & 238.62 & 16 \\
\hline Poland & 74 & 467 & 8 & 5 & 2 & 144 & 100.676 & 12 \\
\hline Spain & 74 & 2108 & 12 & 6 & 10 & 1093 & 278.29 & 26 \\
\hline Canada & 69 & 1746 & 4 & 2 & 16 & 1088 & 214.86 & 27 \\
\hline Greece & 63 & 3169 & 8 & 4 & 18 & 2530 & 188.375 & 28 \\
\hline South Korea & 62 & 767 & 9 & 6 & 1 & 171 & 187.285 & 15 \\
\hline France & 60 & 448 & 8 & 5 & 0 & 0 & 97.593 & 11 \\
\hline India & 41 & 807 & 3 & 2 & 5 & 610 & 98.301 & 12 \\
\hline Turkey & 41 & 347 & 1 & 2 & 1 & 51 & 99.477 & 10 \\
\hline Denmark & 38 & 348 & 5 & 1 & 2 & 126 & 91.441 & 10 \\
\hline Netherlands & 37 & 551 & 6 & 1 & 1 & 60 & 43.258 & 14 \\
\hline Taiwan & 37 & 1487 & 8 & 4 & 4 & 1141 & 123.366 & 13 \\
\hline Australia & 35 & 910 & 1 & 1 & 4 & 649 & 87.782 & 11 \\
\hline Sweden & 32 & 515 & 4 & 3 & 3 & 338 & 77.904 & 10 \\
\hline
\end{tabular}


Furthermore, the results indicate that more publications originate from China, the United States, and Italy than all the other countries put together, accounting for $40.27 \%$ of the total ORC publications. The research output of different countries is presented as a standard score of a single research indicator and also as accumulative (the sum of standard scores of all research indicators). The results are depicted in Figure 4.

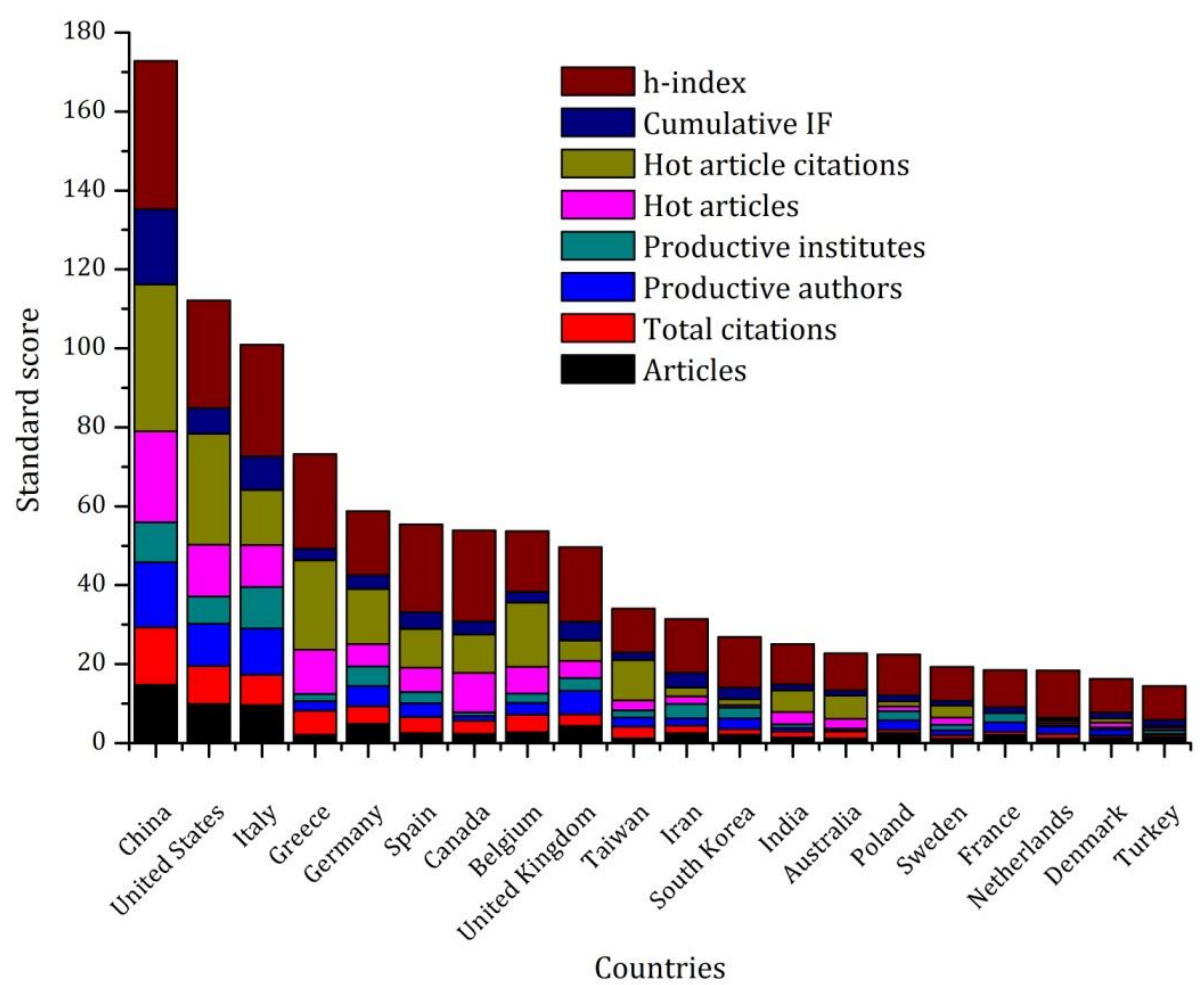

Figure 4: Standard research output score of the most productive countries

China, the United States, and Italy are still the leading countries in terms of the number of publications as well as the standard score of research output, attaining values of 172, 112, and 100 , respectively. The standard score indicates that the number of publications alone does not indicate the quality of research output. For example, Greece is at the 11th position with 63 as the number of publications, but stands at the fourth position with respect to the standard score of research output indicators (having a value of 73) when the impact factor, citations, hot articles, productive authors, and productive institutes are considered.

\subsection{Journal distribution}

The source of publications was analyzed to identify the journals with the highest share of publications. The 10 most productive journals/publishers in the ORC field are shown in Table 3. The Energy journal has the largest share of publications and accounts for $12.35 \%$ of the total ORC publications from 2000 to 2016. The top 10 journals account for $47.78 \%$ of the total ORC publications. Energy and Applied Thermal Engineering, and Applied Energy have more than 37 citations per publication and an h-index of more than 110 . These three journals account for 30 $\%$ of the total ORC publications and $56 \%$ of the total citations. The percentage of the papers, citations, and journal quality indicate that these journals are the leading journals in the field of ORC power systems. The publishing houses of these journals originate from three countries, namely, the USA, the UK, and the Netherlands. 
Table 3: Top 10 productive journals in the ORC technology field from 2000 to 2016

\begin{tabular}{lccccccc}
\hline \multirow{2}{*}{ Journal } & \multicolumn{2}{c}{ Total } & \multicolumn{2}{c}{ Relative (\%) } & \multicolumn{3}{c}{ Journal quality } \\
& Papers & Citation & Papers & Citation & h-index & IF & SNP \\
\hline Energy & 262 & 9719 & 12.36 & 26.45 & 134 & 4.52 & 1.798 \\
Applied Thermal Engineering & 180 & 7078 & 8.49 & 19.27 & 112 & 3.356 & 1.828 \\
$\begin{array}{l}\text { Energy Conversion and } \\
\text { Management }\end{array}$ & 136 & 3857 & 6.42 & 10.50 & 139 & 5.589 & 2.065 \\
$\begin{array}{l}\text { Applied Energy } \\
\text { Energy Procedia }\end{array}$ & 98 & 3537 & 4.62 & 9.63 & 125 & 7.182 & 2.573 \\
$\begin{array}{l}\text { Proceedings of the ASME } \\
\text { Turbo Expo }\end{array}$ & 75 & 324 & 4.10 & 0.88 & 51 & NA & NA \\
$\begin{array}{l}\text { Transactions - Geothermal } \\
\text { Resources Council }\end{array}$ & 59 & 149 & 2.78 & 0.41 & 20 & NA & NA \\
$\begin{array}{l}\text { Energies } \\
\text { Journal of Engineering for }\end{array}$ & 46 & 324 & 2.17 & 0.88 & 48 & 2.262 & NA \\
$\begin{array}{l}\text { Gas Turbines and Power } \\
\text { Renewable Energy }\end{array}$ & 34 & 437 & 1.70 & 1.19 & 66 & 1.534 & NA \\
\hline
\end{tabular}

2 The timeline of the publications in the top journals is shown in Figure 5.

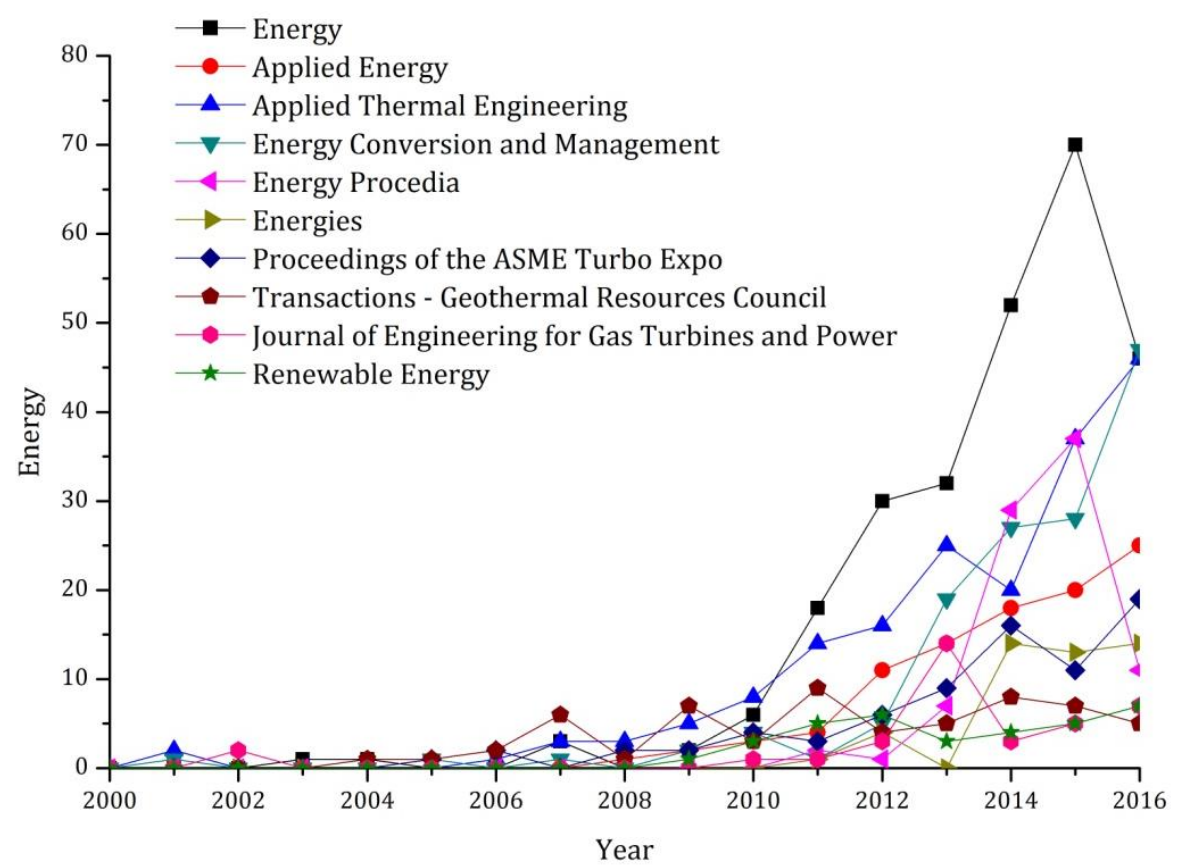

Figure 5: Timeline of ORC publications of the most productive journals from 2000 to 2016

The exponential rise in publications is observed from 2010 and onwards. The Energy journal is the leading journal in number of publications from the early 2000 to the present with more than 70 publications in 2015 .

\subsection{Subject distribution}

Research work in the ORC field can be broadly classified into six major categories including applications of the ORC technology, working fluids, expansion machines, cycle architecture, design and optimization, and dynamics and control of ORC systems. The distribution of ORC publications on the basis of the major core research areas is shown in Figure 6. 

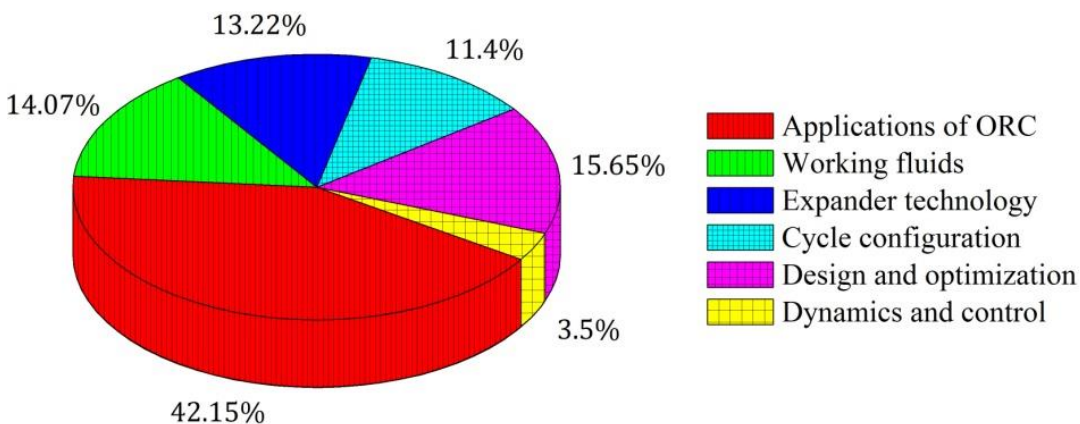

1

Figure 6: Distribution of core research areas of the ORC

The largest share of publications, $42.15 \%$, deals with the application of ORC technology which can further be classified into solar, geothermal, biomass, waste heat recovery, and ocean thermal energy based ORC systems. The topic of dynamic modeling and control of ORC systems has a relatively low share of publications, about $3.5 \%$, which can be explained by the recent interest in the development of mini-ORC units for automotive applications - an area of which the control aspect is of crucial importance. In the case of most other applications of the ORC, the temperature and mass flow rate profile is relatively constant, making the control logics simpler. The major core research areas are further categorized into sub-research areas as shown in Figure 7.

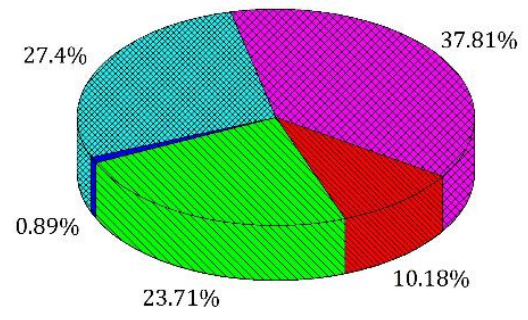

Applications of ORC technology $67.88 \%$

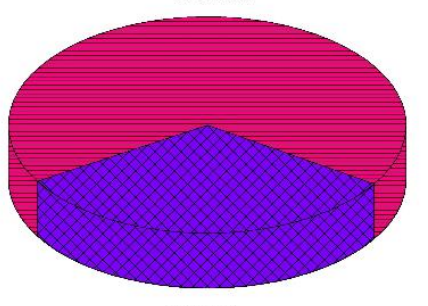

$32.12 \%$

ORC system design and optimization $27.57 \%$

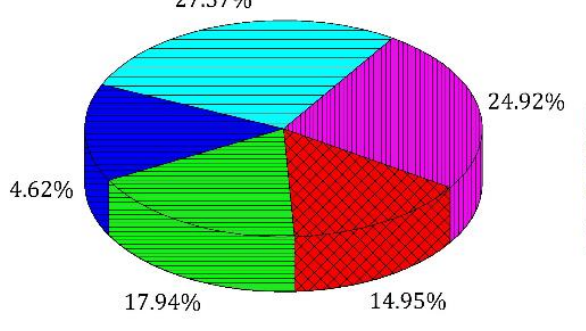

Working fluids for ORC systems

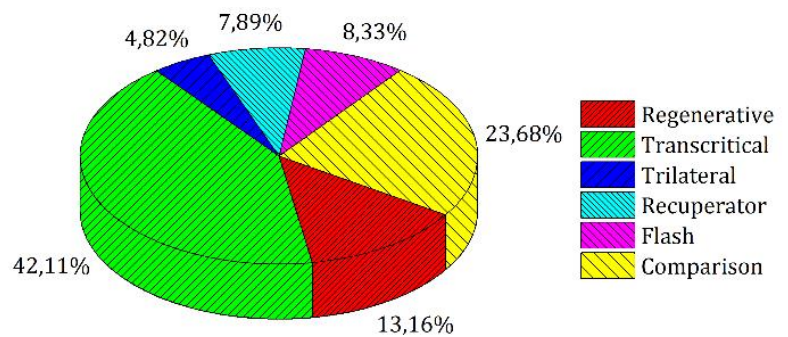

Cycle configuration of ORC

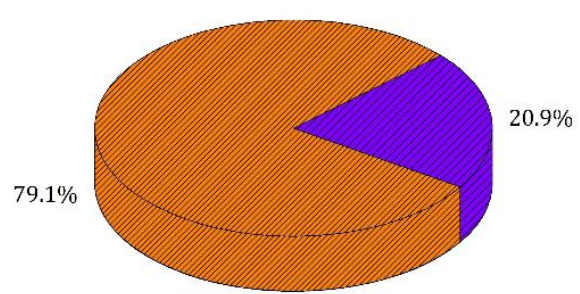

Dynamics and control of ORC systems

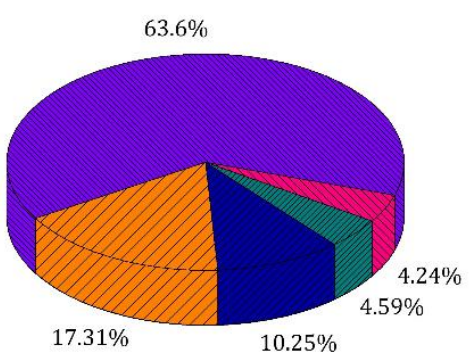

Expanders selection for ORC systems 
1 The number of publications in the core research areas of the ORC has increased significantly 2 from 2008 to 2016 . The timeline of the core research areas and the number of the publications 3 are shown in Figure 8.

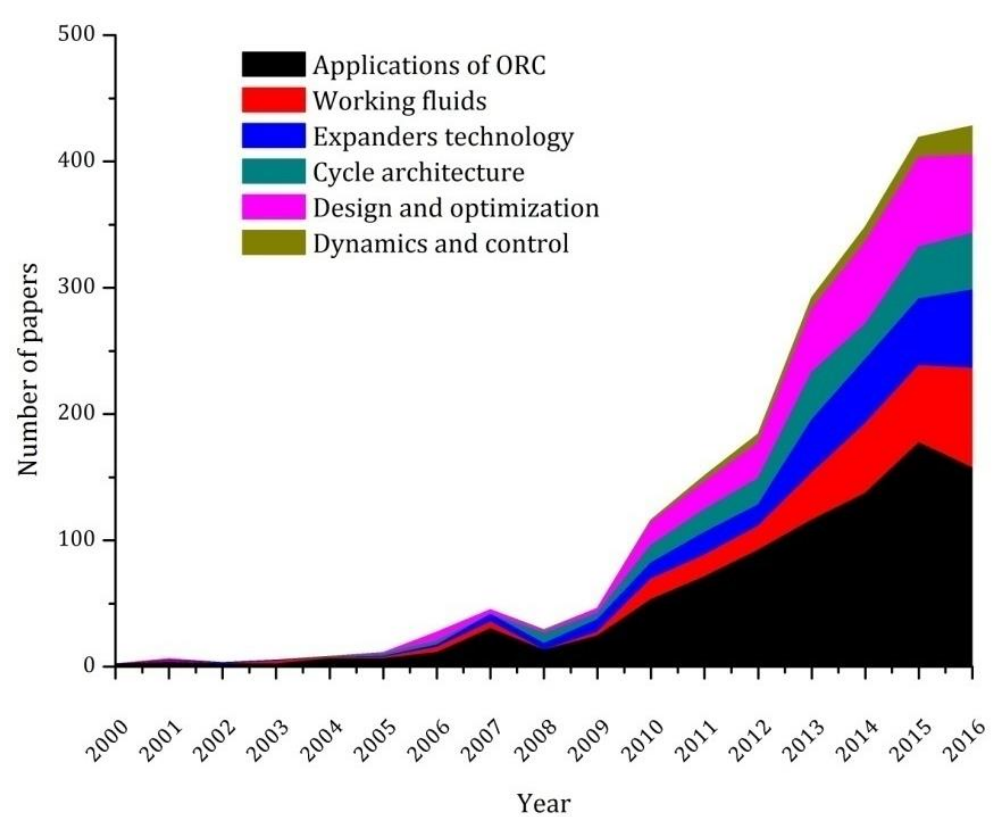

Figure 8: Core research areas and publication timeline

During the search in Scopus, the subject areas are restricted to physical sciences and social sciences only. Figure 9 depicts the research publications in the ORC field according to subject categories.

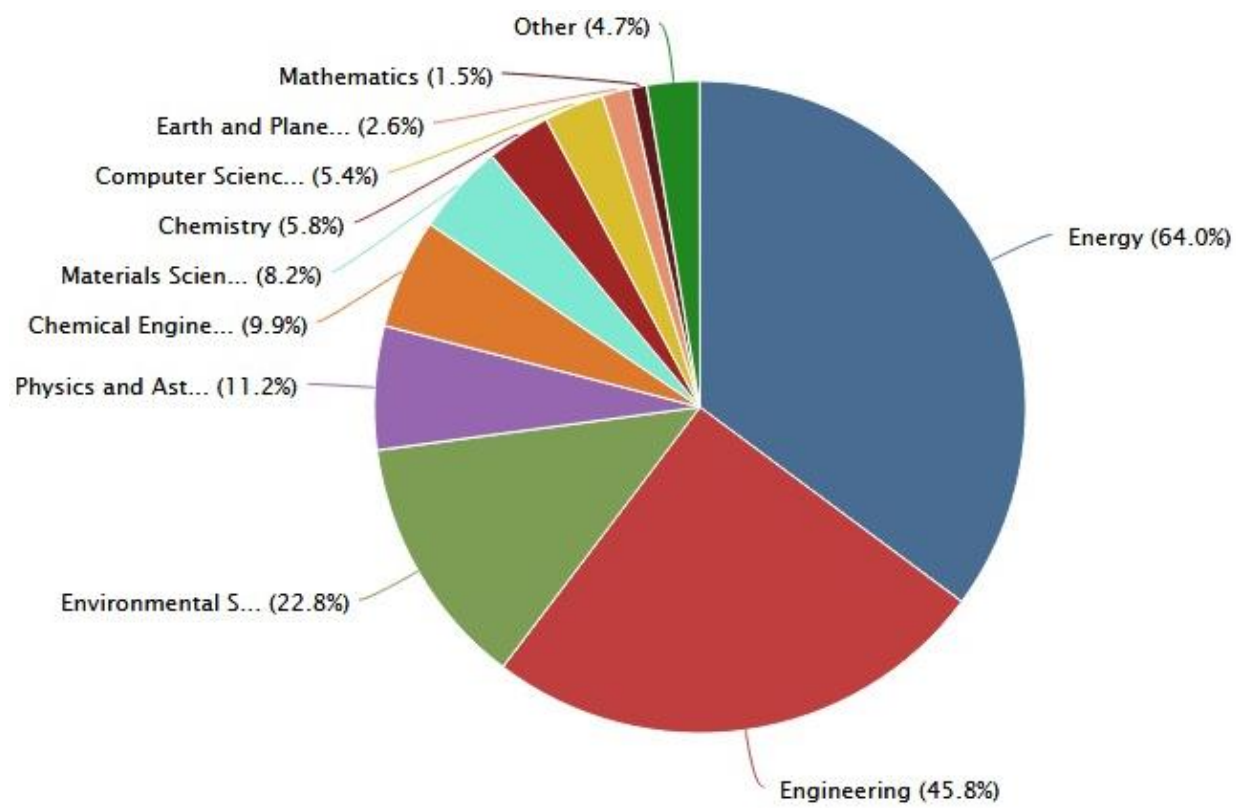

Figure 9: Publication distribution according to subjects classified by Scopus

The research work in the ORC field mainly falls into engineering, energy, and environmental studies. It should be noted that one publication may be listed in more than one subject category. Moreover, it can be noted that only $11 \%$ of the total ORC publications are based on experimental data or experimental verification. 


\section{$1 \quad 3.5 \quad$ Authorship pattern}

2 The authorship results suggest that these 2120 articles were published by 3443 authors from 371 countries. Statistical analysis indicates that 321 authors are productive authors, that is, 4 authors who have published five or more papers. Productive authors account for $13.2 \%$ of the 5 total authors, and their contribution in total ORC publications is about $21.7 \%$. The authorship 6 pattern is shown in Figure 10.

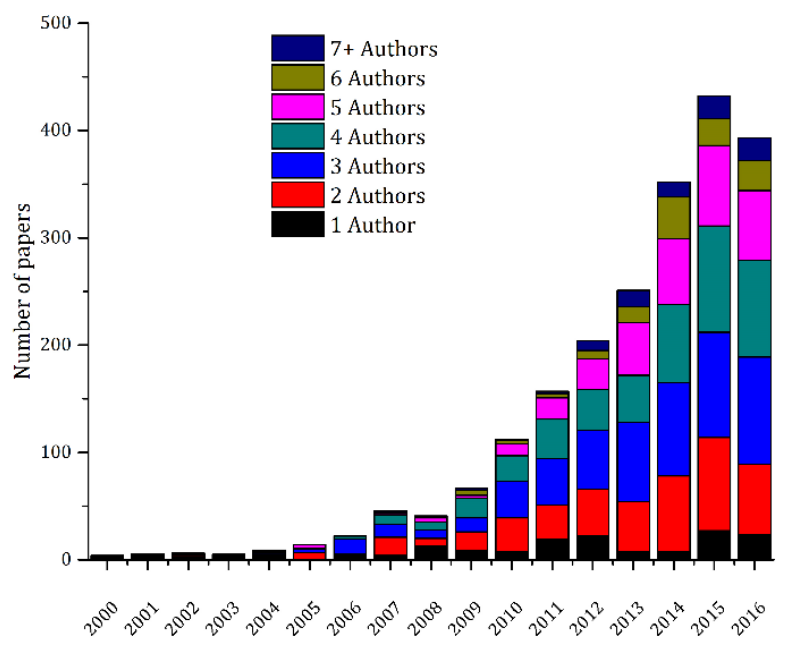

Figure 10: Authorship pattern in the field of ORC publications from 2000 to 2016

The authorship pattern was also analyzed on the basis of the number of authors per publication. It can be seen from Figure 10 that papers with three authors in a paper make up $25 \%$ of the total ORC publications. The result of the authorship pattern indicates that the number of papers with two, three, and four authors, makes up the maximum number of papers, accounting for $67.2 \%$ of the total number of ORC publications. The 10 most productive authors in the ORC technology field are listed in descending order of total number of publications in Table 4.

Table 4: Top 10 authors in the ORC technology field during 2000-2016

\begin{tabular}{|c|c|c|c|c|c|c|c|c|c|}
\hline Author & Institute & ТP & CT & $\mathrm{IF}$ & CPP & IFPP & h-index & HA & HACT \\
\hline Dincer I. & $\begin{array}{l}\text { University of Ontario Institute } \\
\text { of Technology, Canada }\end{array}$ & 38 & 1336 & 146 & 35 & 3.84 & 21 & 13 & 919 \\
\hline Quoilin S. & University of Liege, Belgium & 36 & 1725 & 71 & 48 & 1.97 & 12 & 8 & 1563 \\
\hline Lemort V. & University of Liege, Belgium & 35 & 1705 & 68 & 49 & 1.94 & 12 & 8 & 1563 \\
\hline Haglind F. & $\begin{array}{l}\text { Technical University of } \\
\text { Denmark, Denmark }\end{array}$ & 31 & 322 & 79 & 10 & 2.55 & 10 & 2 & 126 \\
\hline Tian $\mathrm{H}$. & Tianjin University, China & 28 & 532 & 101 & 19 & 3.61 & 11 & 5 & 338 \\
\hline Shu G. & Tianjin University, China & 28 & 532 & 101 & 19 & 3.61 & 11 & 5 & 338 \\
\hline Dai Y. & $\begin{array}{l}\text { Xi'an Jiaotong University, } \\
\text { China }\end{array}$ & 25 & 1124 & 96 & 45 & 3.84 & 13 & 6 & 846 \\
\hline Colonna P. & $\begin{array}{l}\text { Delft University of Technology, } \\
\text { Netherlands }\end{array}$ & 24 & 489 & 32 & 20 & 1.33 & 14 & 1 & 60 \\
\hline Wang J. & $\begin{array}{l}\text { Xi'an Jiaotong University, } \\
\text { China }\end{array}$ & 23 & 1087 & 84 & 47 & 3.65 & 13 & 6 & 848 \\
\hline Papadakis G. & $\begin{array}{l}\text { Agricultural University of } \\
\text { Athens, Greece }\end{array}$ & 22 & 1524 & 92 & 69 & 4.18 & 16 & 8 & 1203 \\
\hline
\end{tabular}


1 The most productive author is Ibrahim Dincer, also named one of the most influential scientific 2 minds in 2014 in Engineering by Thomson Reuters due to his top $1 \%$ of total citations in the 3 field of energy. The generalized statistics show that out of the top 10 authors, five are from 4 Europe and four are from China. The influence of authors has been investigated on the basis of 5 total number of publications (TP), citations (CT), impact factor (IF), citation per publication 6 (CPP), impact factor per publication (IFPP), h-index, hot articles (HA), and hot article citations 7 (HACT). The highest citation per publication is 69 by Papadakis G., the highest impact factor per 8 publication is 4.18 by Papadakis G., and the highest number of hot articles are written by Dincer 9 I. totaling 13. Lemort V. and Quoilin S. have the highest number of total citations, 1725 citations 10 from 36 publications.

\subsection{Institutional statistics}

The result shows that the publications are distributed among 997 research institutes across the world. The number of productive institutes are 159 , and these account for $82.57 \%$ of the ORC publications. The details of the leading research institutes are shown in Table 5 (listed in descending order of total number of publications). These research institutes have published $31.58 \%$ of the total ORC publications from 2000 to 2016.

Table 5: Most productive institutes in the ORC technology field from 2000 to 2016

\begin{tabular}{|c|c|c|c|c|c|c|c|c|}
\hline \multirow{2}{*}{ Institute } & \multicolumn{4}{|c|}{ Key indicators } & \multicolumn{4}{|c|}{ Relative performance (\%) } \\
\hline & Papers & IF & h-index & TC & Papers & $\mathrm{IF}$ & h-index & TC \\
\hline Tianjin University, China & 98 & 313 & 22 & 1943 & 4.6 & 6.8 & 26.5 & 5.3 \\
\hline Ministry of Education China, China & 70 & 200 & 16 & 817 & 3.3 & 4.4 & 19.3 & 2.2 \\
\hline Xi'an Jiaotong University, China & 57 & 169 & 18 & 1466 & 2.7 & 3.7 & 21.7 & 4.0 \\
\hline $\begin{array}{lll}\text { North China } & \text { Electric } & \text { Power } \\
\text { University, China } & & \end{array}$ & 50 & 117 & 14 & 656 & 2.4 & 2.5 & 16.9 & 1.8 \\
\hline Polytechnic University of Milan, Italy & 47 & 106 & 17 & 1093 & 2.2 & 2.3 & 20.5 & 3.0 \\
\hline $\begin{array}{l}\text { University of Ontario Institute of } \\
\text { Technology, Canada }\end{array}$ & 43 & 165 & 22 & 1430 & 2.0 & 3.6 & 26.5 & 3.9 \\
\hline Tsinghua University, China & 43 & 143 & 15 & 743 & 2.0 & 3.1 & 18.1 & 2.0 \\
\hline University of Liege, Belgium & 41 & 70 & 11 & 1726 & 1.9 & 1.5 & 13.3 & 4.7 \\
\hline Gent University, Belgium & 34 & 77 & 9 & 741 & 1.6 & 1.7 & 10.8 & 2.0 \\
\hline $\begin{array}{l}\text { National Technical University of } \\
\text { Athens, Greece }\end{array}$ & 34 & 87 & 16 & 1117 & 1.6 & 1.9 & 19.3 & 3.0 \\
\hline $\begin{array}{l}\text { Technical University of Denmark, } \\
\text { Denmark }\end{array}$ & 33 & 85 & 10 & 336 & 1.6 & 1.9 & 12.0 & 0.9 \\
\hline University of Padua, Italy & 32 & 82 & 11 & 329 & 1.5 & 1.8 & 13.3 & 0.9 \\
\hline $\begin{array}{l}\text { Delft University of Technology, } \\
\text { Netherlands }\end{array}$ & 32 & 43 & 14 & 528 & 1.5 & 0.9 & 16.9 & 1.4 \\
\hline $\begin{array}{l}\text { Beijing University of Technology, } \\
\text { China }\end{array}$ & 28 & 99 & 13 & 786 & 1.3 & 2.2 & 15.7 & 2.1 \\
\hline Shanghai Jiaotong University, China & 27 & 63 & 10 & 749 & 1.3 & 1.4 & 12.0 & 2.0 \\
\hline
\end{tabular}
ten research institutes, five institutes are from China, two from Belgium, and one research institute each from Canada, Italy, Denmark, and Greece. 
1 The research output of these institutes relative to the total ORC publications from 2000-2016 is shown in Figure 11.

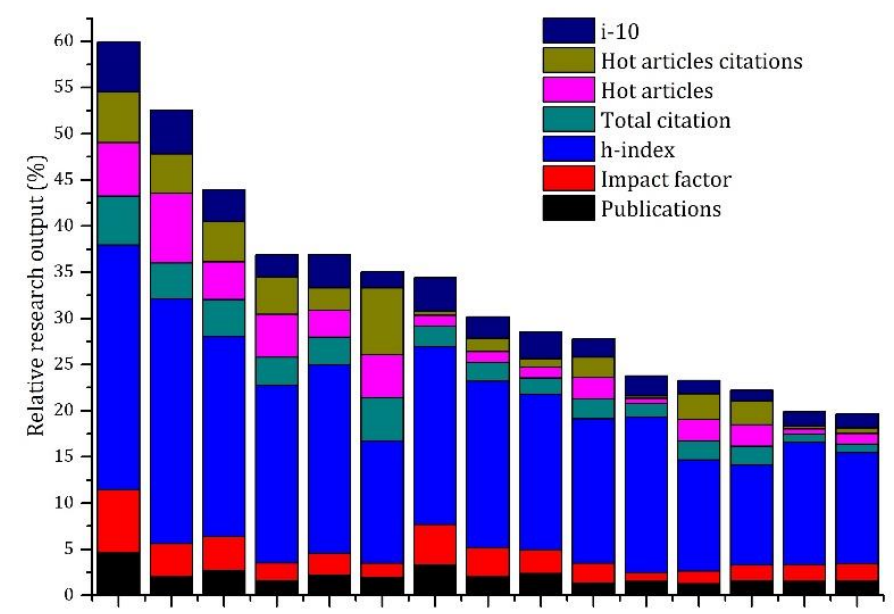

Figure 11: Relative research output of the leading research institutes in the ORC technology field

The relative research output of these institutes shows that the share of hot articles and hot article citations of these institutes to the total ORC publications is about $42 \%$ and $39 \%$, respectively. The National Technical University of Athens is at number 10 with 34 as their number of publications, but it stands at number four when all the research indicators are taken into account. The timeline of publications of these research institutes is shown in Figure 12.

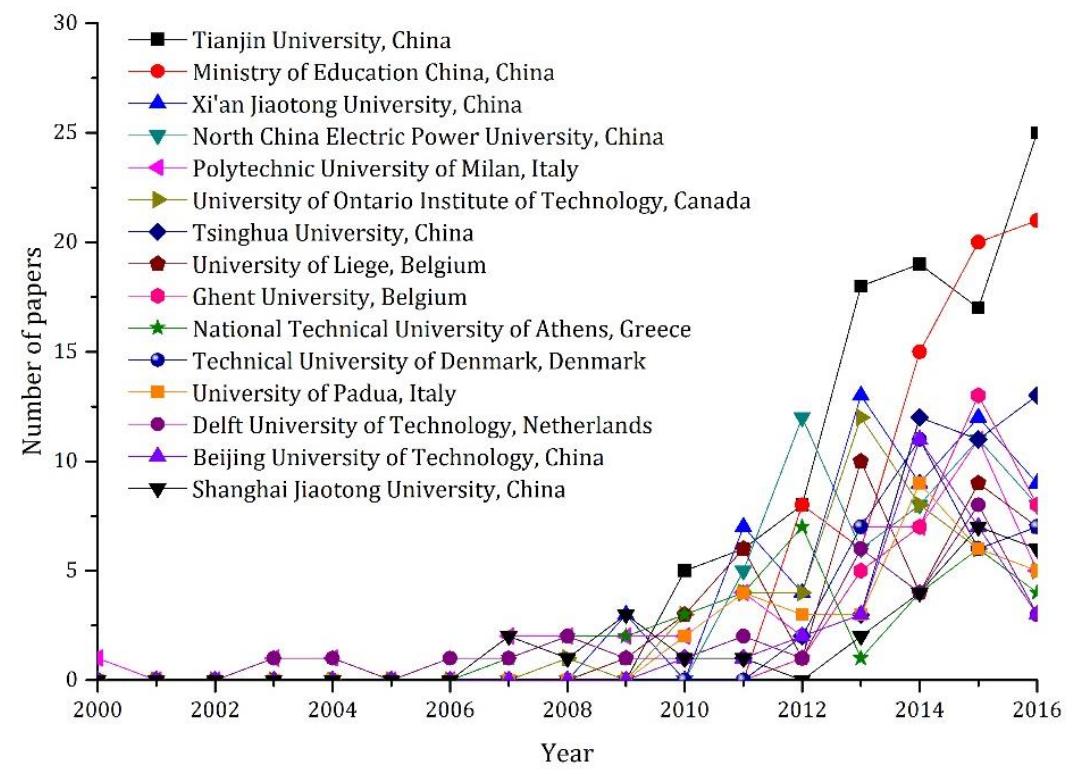




\subsection{Academic collaboration}

2 The level of degree of collaboration, as quantified in Equations (1) to (3), is shown in Figure 13. 3 From 2000 to 2016 there are decreasing trends in collaboration according to the auctorial, the 4 institutional and the national degree of collaboration indicators.

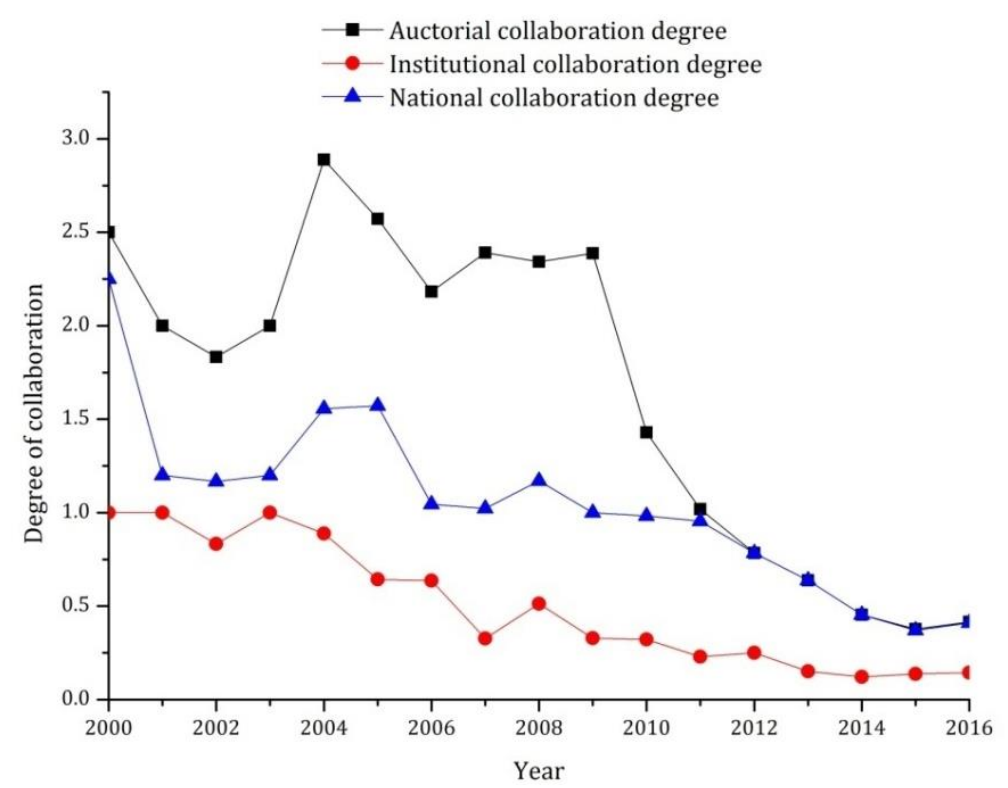

Figure 13: Auctorial, institutional and national collaboration degrees

It may be observed that the auctorial degree has decreased from 2.5 in 2000 to 0.5 in 2016, the institutional degree has decreased from 2.4 in 2000 to 0.5 in 2016, and the national degree has decreased from 1.0 in 2000 to 0.25 in 2016. The average degree of collaboration (sum of auctorial, institutional and national collaboration degrees) is shown in Figure 14. The results suggest that, on average, from 2000 to 2016, 1.6 authors, 1 institute, and 0.5 country have participated in each publication. The lower values of the collaboration degree show that the ORC publications are concentrated to only a few countries and institutes.

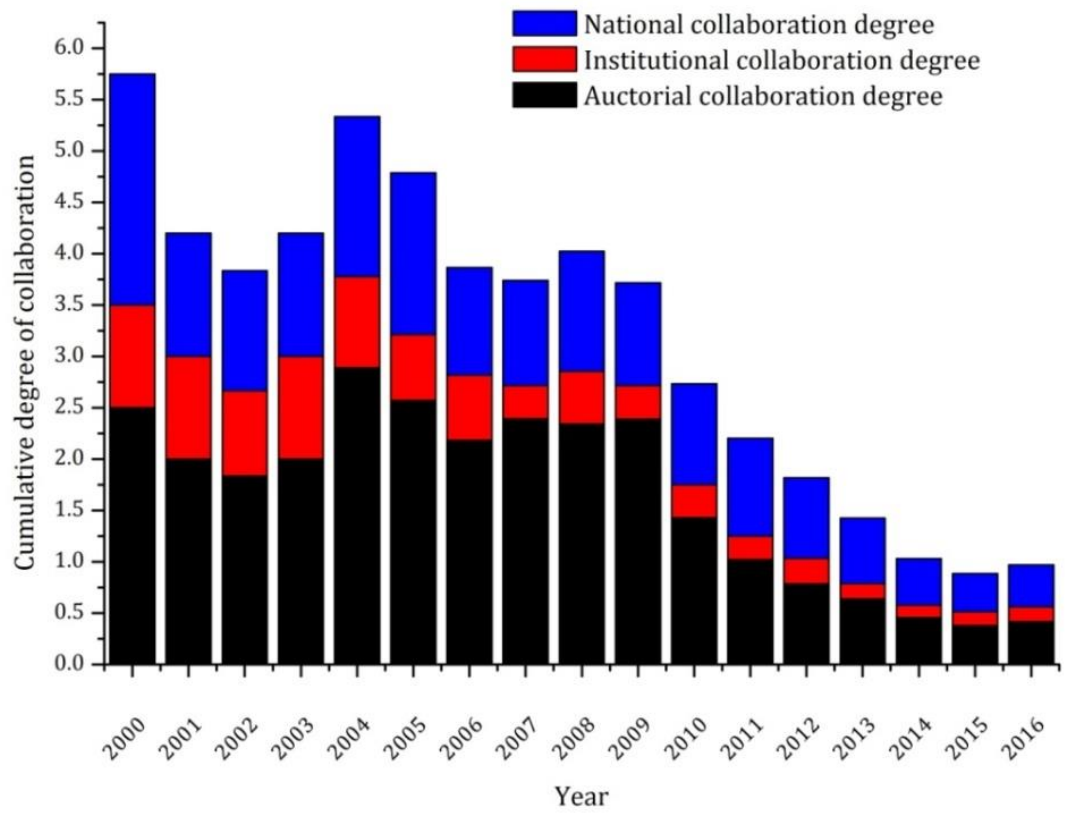

Figure 14: Timeline of average degree of collaboration in the ORC technology field from 2000 to 2016 


\section{$1 \quad 3.8 \quad$ Article citation}

2 The citation pattern was investigated in terms of the hot articles, i-10, and h-index from 2000 to 3 2016. The timeline of the citation pattern of the ORC publications is shown in Table 6.

Table 6: Publication statistics of ORC publications from 2000 to 2016

\begin{tabular}{cccccccccc}
\hline \multirow{2}{*}{ Year } & \multicolumn{3}{c}{ Publications } & \multicolumn{2}{c}{ Total } & \multicolumn{2}{c}{ Hot article } & \multicolumn{2}{c}{ Quality } \\
& Cited & Un-cited & Total & Citation & IF & No. & Citation & $i-10$ & h-index \\
\hline 2016 & 256 & 137 & 393 & 1132 & 1092 & 0 & 0 & 27 & 13 \\
2015 & 330 & 102 & 432 & 2898 & 975 & 0 & 0 & 102 & 23 \\
2014 & 284 & 68 & 352 & 3772 & 790 & 9 & 512 & 135 & 32 \\
2013 & 205 & 46 & 251 & 5162 & 576 & 29 & 2521 & 120 & 40 \\
2012 & 166 & 38 & 204 & 4304 & 432 & 28 & 2413 & 94 & 36 \\
2011 & 133 & 24 & 157 & 5141 & 285 & 34 & 3999 & 68 & 39 \\
2010 & 87 & 25 & 112 & 4157 & 162 & 22 & 3438 & 44 & 30 \\
2009 & 54 & 13 & 67 & 2759 & 83 & 16 & 2334 & 27 & 21 \\
2008 & 38 & 3 & 41 & 1227 & 53 & 7 & 880 & 20 & 15 \\
2007 & 35 & 11 & 46 & 2912 & 83 & 10 & 2431 & 26 & 20 \\
2006 & 15 & 7 & 22 & 329 & 5 & 1 & 214 & 6 & 7 \\
2005 & 12 & 2 & 14 & 355 & 21 & 4 & 266 & 8 & 8 \\
2004 & 9 & 0 & 9 & 1254 & 17 & 3 & 1146 & 6 & 6 \\
2003 & 3 & 2 & 5 & 193 & 8 & 1 & 137 & 2 & 3 \\
2002 & 5 & 1 & 6 & 89 & 3 & 1 & 54 & 3 & 4 \\
2001 & 5 & 0 & 5 & 972 & 11 & 4 & 970 & 4 & 4 \\
2000 & 2 & 2 & 4 & 83 & 1 & 1 & 50 & 2 & 2 \\
\hline
\end{tabular}

5 The result suggests that the number of publications and corresponding citations has an 6 increasing trend, and the highest values of hot articles, i-10, and h-index can been observed 7 from 2010 to 2013. The highest citation counts are 5141 in the year 2011. Since the number of 8 citable documents is increasing, it is expected that the number of citations will have an 9 increasing trend from 2013 and onwards as well. The number of citations per publication (CPP) 10 is an effective tool to evaluate the productivity of the research. The number of citations per 11 publication and the impact factor per publication from 2000 to 2016 are shown in Figure 15.

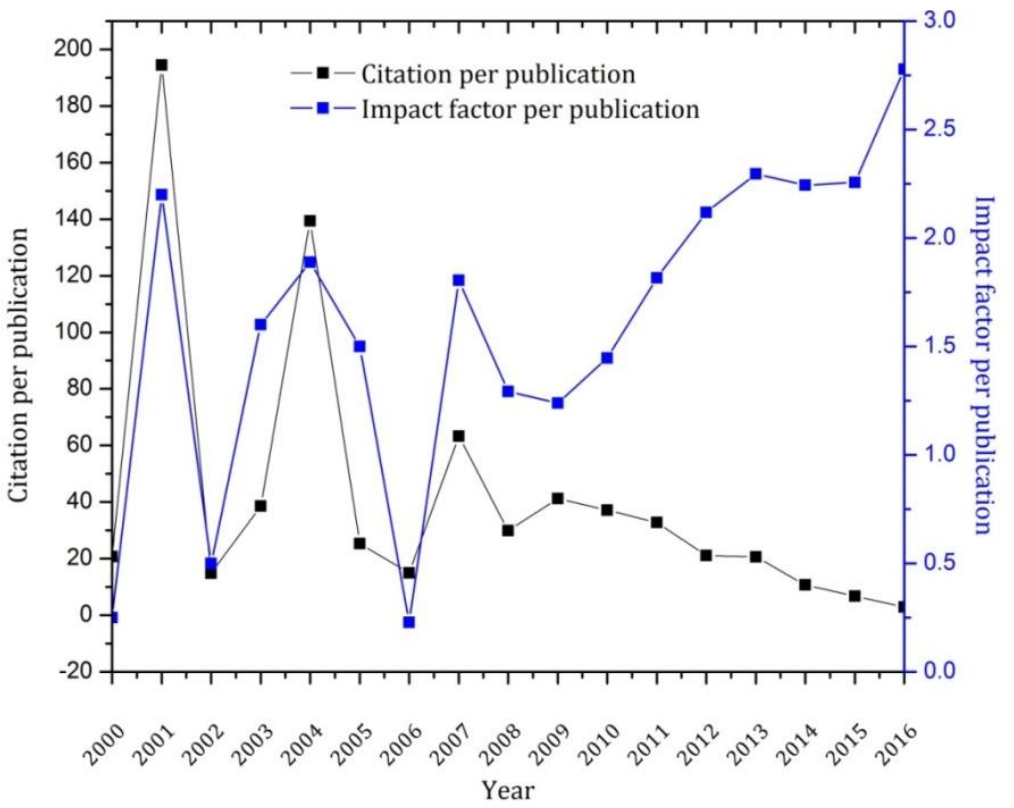


1 It can be observed that the CPP has overall a decreasing trend with the highest value of 194 in 2 2003. From 2009 to 2016, a decreasing trend indicates the number of published papers has 3 increased significantly, and most of these articles do not have even a single citation. The un4 cited documents have increased from 13 in 2009 to 137 in 2016. However, the impact factor per 5 publication has an increasing trend from 2008 onwards. The impact factor per publication has 6 increased from 1.4 in 2010 to 2.8 in 2016.

7 The 15 most cited articles are listed in Table 7 . These highly cited articles account for $16.43 \%$ of 8 the total number of citations. Out of these15 highly cited articles, three originate from the USA, 9 three from China, five from Europe, and two from Taiwan. These 15 highly cited articles are 10 published with Elsevier in its leading journals in the field of energy. Out of these 15 highly cited 11 articles, four papers are published in Applied Thermal Engineering, four in Energy, three in 12 Energy Conversion and Management, and three in Renewable and Sustainable Energy Reviews.

Table 7: The 15 most cited articles in the ORC technology field from 2000 to 2016

\begin{tabular}{lllccl}
\hline \multicolumn{1}{c}{ Author } & \multicolumn{1}{c}{ Country } & Year & $\begin{array}{c}\text { Total } \\
\text { Citations }\end{array}$ & $\begin{array}{c}\text { Relative } \\
\text { Citations (\%) }\end{array}$ & Journal \\
\hline Saleh B. [43] & Austria & 2007 & 711 & 1.94 & Energy \\
Chen H.[13] & United States & 2010 & 490 & 1.33 & Renew Sust Energ Rev \\
Liu B.-T. [44] & Taiwan & 2004 & 467 & 1.27 & Energy \\
Madhawa H.D. [45] & United States & 2007 & 453 & 1.23 & Energy \\
Mills D. [46] & Australia & 2004 & 437 & 1.19 & Solar Energy \\
Dai Y. [47] & China & 2009 & 399 & 1.09 & Energ Convers Manage \\
Hung T.C. [48] & Taiwan & 2001 & 385 & 1.05 & Energ Convers Manage \\
Tchanche B.F.[6] & Greece & 2011 & 375 & 1.02 & Renew Sust Energ Rev \\
Drescher U. [49] & Germany & 2007 & 372 & 1.01 & Appl Therm Eng \\
Tchanche B.F. [50] & Greece & 2009 & 362 & 0.99 & Appl Therm Eng \\
Wei D. [51] & China & 2007 & 338 & 0.92 & Energ Convers Manage \\
Yamamoto T. [52] & Japan & 2001 & 338 & 0.92 & Energy \\
S. Quoilin [3] & Belgium & 2013 & 306 & 0.83 & Renew Sust Energ Rev \\
Shengjun Z. [53] & China & 2011 & 301 & 0.82 & Applied Energy \\
Mago P.J. [54] & United States & 2008 & 300 & 0.82 & Appl Therm Eng \\
\hline
\end{tabular}

\section{$14 \quad 3.9 \quad$ Research hotspots}

The most frequently used keywords among the ORC publications were also analyzed. The frequency of the keywords is shown in Table 8.

Table 8: Frequency of keywords in the ORC publications from 2000 to 2016

\begin{tabular}{clcclc}
\hline Rank & \multicolumn{1}{c}{ Words } & Frequency & Rank & \multicolumn{1}{c}{ Words } & Frequency \\
\hline 1 & Organic Rankine Cycle & 1086 & 11 & Biomass & 58 \\
2 & Waste Heat Recovery & 264 & 12 & Geothermal energy & 56 \\
3 & ORC & 234 & 13 & Efficiency & 53 \\
4 & Working fluid & 122 & 14 & Scroll Expander & 52 \\
5 & Exergy & 103 & 15 & Waste heat & 50 \\
6 & Optimization & 101 & 16 & Geothermal & 46 \\
7 & Solar Energy & 86 & 17 & Heat recovery & 46 \\
8 & Energy efficiency & 69 & 18 & Thermal efficiency & 46 \\
9 & Rankine cycle & 66 & 19 & Zeotropic mixtures & 45 \\
10 & Exergy analysis & 60 & 20 & Power Generation & 44 \\
\hline
\end{tabular}


Around 2864 keywords have been used in total, and the keyword "Organic Rankine Cycle" accounts for $38 \%$ of occurrences of keywords. The most commonly used keyword mostly focused on the application of ORC technology, such as waste heat recovery, solar, biomass, geothermal, etc. The timeline of the frequency of keywords is shown in Figure 16.

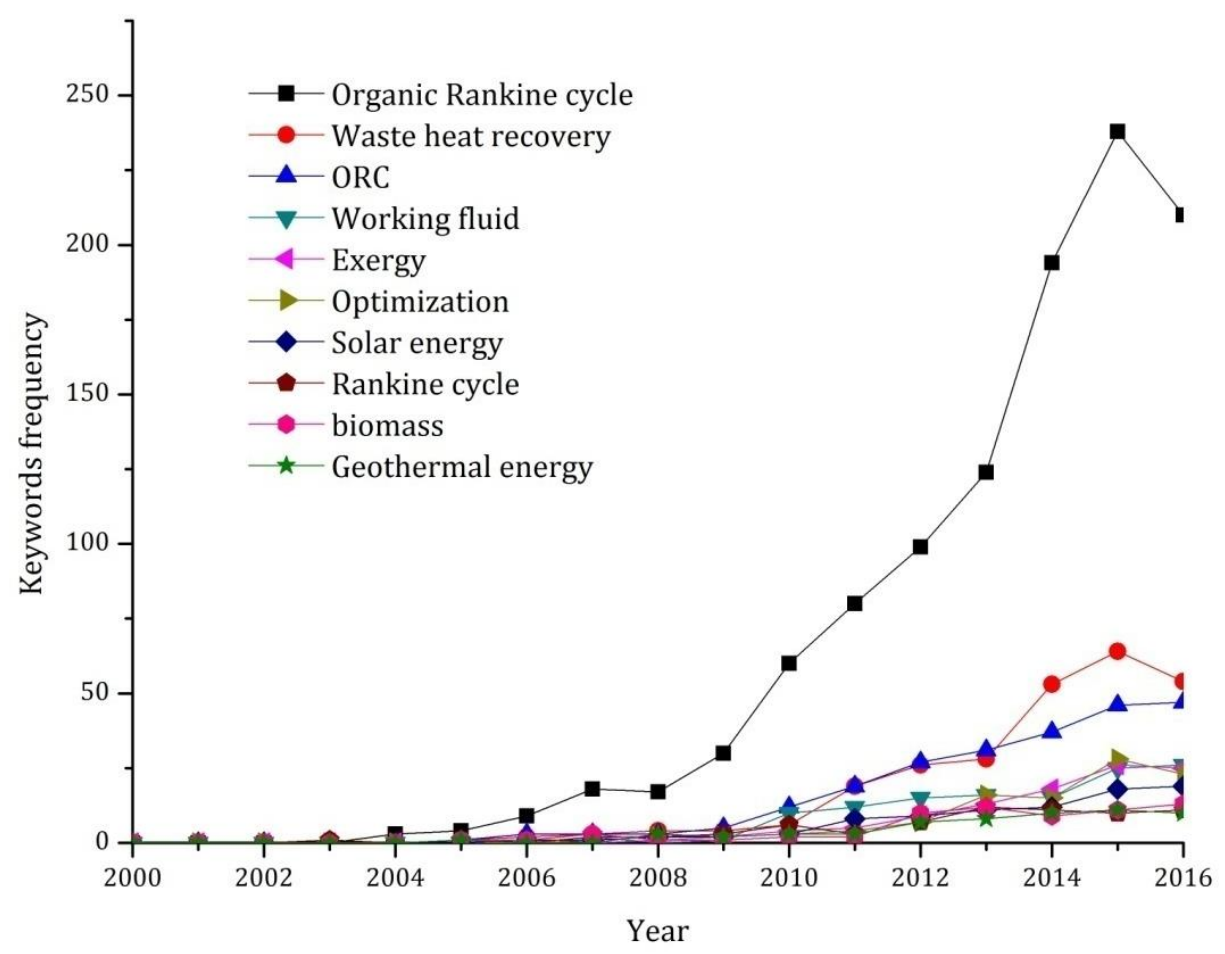

\section{$7 \quad 4 . \quad$ Concluding remarks} publications.

From 2000 to 2016, 2120 articles were published in the ORC technology field by Scopus indexed journals and conference proceedings by 3443 authors from 997 research institutes originating from 71 countries. The total impact factor and citations of ORC publications amount to 4597 and 36739 , respectively. The publications originate mainly from China, the USA, and Europe. The top 10 leading countries and research institutes account for $65.8 \%$ and $24.4 \%$ of the total ORC publications, respectively. From 2000 to 2016, 1.5 authors, 1.5 institutes, and 0.5 country have participated on average in each publication, indicating that ORC research is concentrated to few countries and institutes. The most productive journal is Energy with 262 publications; the highest cited article [43] is also published in Energy and it accounts for $2 \%$ of the total citations. The most productive author is Ibrahim Dincer, who has 38 papers with 35 citations per publication and an impact factor per publication of 3.8; the most productive institution is Tianjin University China with 98 publications. According to the analysis of keyword frequency, 2864 keywords have been used in 2120 publications, and the keyword "Organic Rankine Cycle" accounts for $38 \%$ of total keywords. The research work in the ORC field can be broadly classified into six major categories, which are applications of ORC technology, working fluids, expansion machines, cycle architecture, design and optimization, and dynamics and control of ORC systems. The largest share of publications, $42 \%$, deals with the application of ORC technology, while dynamic modeling and control of ORC systems have the lowest share of 


\section{5. Acknowledgement}

2 The research presented in this paper has received funding from the European Union's Horizon 32020 research and innovation programme with a Marie Skłodowska-Curie Fellowship under 4 grant agreement number 751947 (project DYNCON-ORC). The financial support is gratefully acknowledged.

\section{References}

[1] Tchanche BF, Petrissans M, Papadakis G. Heat resources and organic Rankine cycle machines. Renew Sustain Energy Rev 2014;39:1185-99. doi:10.1016/j.rser.2014.07.139.

[2] Imran M, Usman M, Park B-S, Yang Y. Comparative assessment of Organic Rankine Cycle integration for low temperature geothermal heat source applications. Energy 2016;102:473-90. doi:10.1016/j.energy.2016.02.119.

[3] Quoilin S, Broek M Van Den, Declaye S, Dewallef P, Lemort V. Techno-economic survey of organic rankine cycle (ORC) systems. Renew Sustain Energy Rev 2013;22:168-86. doi:10.1016/j.rser.2013.01.028.

[4] Colonna P, Casati E, Trapp C, Mathijssen T, Larjola J, Turunen-Saaresti T, et al. Organic Rankine Cycle Power Systems: From the Concept to Current Technology, Applications, and an Outlook to the Future. J Eng Gas Turbines Power 2015;137:100801. doi:10.1115/1.4029884.

[5] Vélez F, Segovia JJ, Martín MC, Antolín G, Chejne F, Quijano A. A technical, economical and market review of organic Rankine cycles for the conversion of low-grade heat for power generation. Renew Sustain Energy Rev 2012;16:4175-89. doi:10.1016/j.rser.2012.03.022.

[6] Tchanche BF, Lambrinos G, Frangoudakis a., Papadakis G. Low-grade heat conversion into power using organic Rankine cycles - A review of various applications. Renew Sustain Energy Rev 2011;15:3963-79. doi:10.1016/j.rser.2011.07.024.

[7] Lion S, Michos CN, Vlaskos I, Rouaud C, Taccani R. A review of waste heat recovery and Organic Rankine Cycles (ORC) in on-off highway vehicle Heavy Duty Diesel Engine applications. Renew Sustain Energy Rev 2017;79:691-708. doi:10.1016/j.rser.2017.05.082.

[8] Sprouse III C, Depcik C. Review of organic Rankine cycles for internal combustion engine exhaust waste heat recovery. Appl Therm Eng 2013;51. doi:10.1016/j.applthermaleng.2012.10.017.

[9] Saidur R, Rezaei M, Muzammil WK, Hassan MH, Paria S, Hasanuzzaman M. Technologies to recover exhaust heat from internal combustion engines. Renew Sustain Energy Rev 2012;16:5649-59. doi:10.1016/j.rser.2012.05.018.

[10] Tocci L, Pal T, Pesmazoglou I, Franchetti B. Small Scale Organic Rankine Cycle (ORC): A TechnoEconomic Review. Energies 2017;10:413. doi:10.3390/en10040413.

[11] Rahbar K, Mahmoud S, Al-Dadah RK, Moazami N, Mirhadizadeh SA. Review of organic Rankine cycle for small-scale applications. Energy Convers Manag 2017;134. doi:10.1016/j.enconman.2016.12.023.

[12] Bao J, Zhao L. A review of working fluid and expander selections for organic Rankine cycle. Renew Sustain Energy Rev 2013;24:325-42. doi:10.1016/j.rser.2013.03.040.

[13] Chen H, Goswami DY, Stefanakos EK. A review of thermodynamic cycles and working fluids for the conversion of low-grade heat. Renew Sustain Energy Rev 2010;14:3059-67. doi:10.1016/j.rser.2010.07.006.

[14] Modi A, Haglind F. A review of recent research on the use of zeotropic mixtures in power generation systems. Energy Convers Manag 2017;138:603-26. doi:10.1016/j.enconman.2017.02.032.

[15] Bamorovat Abadi G, Kim KC. Investigation of organic Rankine cycles with zeotropic mixtures as a working fluid: Advantages and issues. Renew Sustain Energy Rev 2017;73. doi:10.1016/j.rser.2017.02.020. 
[16] Dai X-Y, An Q-S, Qian W-Z, Shi L. Research progress of the Organic Rankine Cycle working fluids thermal stability. K Cheng Je Wu Li Hsueh Pao/Journal Eng Thermophys 2016;37.

[17] Imran M, Usman M, Lee DH, Park BS. Volumetric expanders for low grade \& waste heat recovery applications. Renew Sustain Energy Rev 2016;57:1090-109. doi:10.1016/j.rser.2015.12.139.

[18] Song P, Wei M, Shi L, Danish SN, Ma C. A review of scroll expanders for organic rankine cycle systems. Appl Therm Eng 2015;75. doi:10.1016/j.applthermaleng.2014.05.094.

[19] Lecompte S, Huisseune H, Van Den Broek M, Vanslambrouck B, De Paepe M. Review of organic Rankine cycle (ORC) architectures for waste heat recovery. Renew Sustain Energy Rev 2015;47. doi:10.1016/j.rser.2015.03.089.

[20] Zhai H, An Q, Shi L, Lemort V, Quoilin S. Categorization and analysis of heat sources for organic Rankine cycle systems. Renew Sustain Energy Rev 2016;64:790-805. doi:10.1016/j.rser.2016.06.076.

[21] Uzun A. National patterns of research output and priorities in renewable energy. Energy Policy 2002;30:131-6. doi:10.1016/S0301-4215(01)00084-2.

[22] Kajikawa Y, Yoshikawa J, Takeda Y, Matsushima K. Tracking emerging technologies in energy research: Toward a roadmap for sustainable energy. Technol Forecast Soc Change 2008;75:77182. doi:10.1016/j.techfore.2007.05.005.

[23] Tsay MY. A bibliometric analysis of hydrogen energy literature, 1965-2005. Scientometrics 2008;75:421-38. doi:10.1007/s11192-007-1785-x.

[24] Konur O. The scientometric evaluation of the research on the algae and bio-energy. Appl Energy 2011;88:3532-40. doi:10.1016/j.apenergy.2010.12.059.

[25] Velvizhi J, Murugesapandian N, Surulinathi M, Srinivasaragavan S. Scientometric profile of solar energy research in India. Recent Res Sci Technol 2011;3:112-7.

[26] Konur 0. The scientometric evaluation of the research on the production of bioenergy from biomass. Biomass and Bioenergy 2012;47:504-15. doi:10.1016/j.biombioe.2012.09.047.

[27] Siegmeier T, Möller D. Mapping research at the intersection of organic farming and bioenergy - A scientometric review. Renew Sustain Energy Rev 2013;25:197-204. doi:10.1016/j.rser.2013.04.025.

[28] Sakata I, Sasaki H. Bibliometric Analysis of International Collaboration in Wind and Solar Energy 2013;1:187-98.

[29] Du H, Wei L, Brown MA, Wang Y, Shi Z. A bibliometric analysis of recent energy efficiency literatures: An expanding and shifting focus. Energy Effic 2013;6:177-90. doi:10.1007/s12053012-9171-9.

[30] Montoya FG, Montoya MG, Gómez J, Manzano-Agugliaro F, Alameda-Hernández E. The research on energy in Spain: A scientometric approach. Renew Sustain Energy Rev 2014;29:173-83. doi:10.1016/j.rser.2013.08.094.

[31] Du H, Li N, Brown MA, Peng Y, Shuai Y. A bibliographic analysis of recent solar energy literatures: The expansion and evolution of a research field. Renew Energy 2014;66:696-706. doi:10.1016/j.renene.2014.01.018.

[32] Mao G, Liu X, Du H, Zuo J, Wang L. Way forward for alternative energy research: A bibliometric analysis during 1994-2013. Renew Sustain Energy Rev 2015;48:276-86. doi:10.1016/j.rser.2015.03.094.

[33] Mao G, Zou H, Chen G, Du H, Zuo J. Past, current and future of biomass energy research: A bibliometric analysis. Renew Sustain Energy Rev 2015;52:1823-33. doi:10.1016/j.rser.2015.07.141.

[34] Zhang P, Yan F, Du C. A comprehensive analysis of energy management strategies for hybrid electric vehicles based on bibliometrics. Renew Sustain Energy Rev 2015;48:88-104. doi:10.1016/j.rser.2015.03.093.

[35] Li K, Pan S, Wei Y. A bibliometric analysis of energy poverty research : results from SCI-E / SSCI databases 2015;38:357-72.

[36] Balakrishnan D, Haney AB, Meuer J. What a MES(s)! A bibliometric analysis of the evolution of 
research on multi-energy systems. Electr Eng 2016;98:369-74. doi:10.1007/s00202-016-0427-9.

[37] Ahi P, Searcy C, Jaber MY. Energy-related performance measures employed in sustainable supply chains: A bibliometric analysis. Sustain Prod Consum 2016;7:1-15. doi:10.1016/j.spc.2016.02.001.

[38] Ferreira Mercuri EG, Jakubiak Kumata AY, Amaral EB, Simões Vitule JR. Energy by Microbial Fuel Cells: Scientometric global synthesis and challenges. Renew Sustain Energy Rev 2016;65:832-40. doi:10.1016/j.rser.2016.06.050.

[39] Chen HQ, Wang X, He L, Chen P, Wan Y, Yang L, et al. Chinese energy and fuels research priorities and trend: A bibliometric analysis. Renew Sustain Energy Rev 2016;58:966-75. doi:10.1016/j.rser.2015.12.239.

[40] Wang Y, Lai N, Zuo J, Chen G, Du H. Characteristics and trends of research on waste-to-energy incineration: A bibliometric analysis, 1999-2015. Renew Sustain Energy Rev 2016;66:95-104. doi:10.1016/j.rser.2016.07.006.

[41] Yu H, Wei YM, Tang BJ, Mi Z, Pan SY. Assessment on the research trend of low-carbon energy technology investment: A bibliometric analysis. Appl Energy 2016;184:960-70. doi:10.1016/j.apenergy.2016.07.129.

[42] Jiang H, Qiang M, Lin P. A topic modeling based bibliometric exploration of hydropower research. Renew Sustain Energy Rev 2016;57:226-37. doi:10.1016/j.rser.2015.12.194.

[43] Saleh B, Koglbauer G, Wendland M, Fischer J. Working fluids for low-temperature organic Rankine cycles. Energy 2007;32:1210-21. doi:10.1016/j.energy.2006.07.001.

[44] Liu BT, Chien KH, Wang CC. Effect of working fluids on organic Rankine cycle for waste heat recovery. Energy 2004;29:1207-17. doi:10.1016/j.energy.2004.01.004.

[45] Madhawa Hettiarachchi HD, Golubovic M, Worek WM, Ikegami Y. Optimum design criteria for an Organic Rankine cycle using low-temperature geothermal heat sources. Energy 2007;32:1698706. doi:10.1016/j.energy.2007.01.005.

[46] Mills D. Advances in solar thermal electricity technology. Sol Energy 2004;76:19-31. doi:10.1016/S0038-092X(03)00102-6.

[47] Dai Y, Wang J, Gao L. Parametric optimization and comparative study of organic Rankine cycle (ORC) for low grade waste heat recovery. Energy Convers Manag 2009;50:576-82. doi:10.1016/j.enconman.2008.10.018.

[48] Hung T-C. Waste heat recovery of organic Rankine cycle using dry fluids. Energy Convers Manag 2001;42:539-53. doi:10.1016/S0196-8904(00)00081-9.

[49] Drescher U, Brüggemann D. Fluid selection for the Organic Rankine Cycle (ORC) in biomass power and heat plants. Appl Therm Eng 2007;27:223-8. doi:10.1016/j.applthermaleng.2006.04.024.

[50] Tchanche BF, Papadakis G, Lambrinos G, Frangoudakis A. Fluid selection for a low-temperature solar organic Rankine cycle. Appl Therm Eng 2009;29:2468-76. doi:10.1016/j.applthermaleng.2008.12.025.

[51] Wei D, Lu X, Lu Z, Gu J. Performance analysis and optimization of organic Rankine cycle (ORC) for waste heat recovery. Energy Convers Manag 2007;48:1113-9. doi:10.1016/j.enconman.2006.10.020.

[52] Yamamoto T, Furuhata T, Arai N, Mori K. Design and testing of the Organic Rankine Cycle. Energy 2001;26:239-51. doi:10.1016/S0360-5442(00)00063-3.

[53] Shengjun Z, Huaixin W, Tao G. Performance comparison and parametric optimization of subcritical Organic Rankine Cycle (ORC) and transcritical power cycle system for low-temperature geothermal power generation. Appl Energy 2011;88:2740-54. doi:10.1016/j.apenergy.2011.02.034.

[54] Mago PJ, Chamra LM, Srinivasan K, Somayaji C. An examination of regenerative organic Rankine cycles using dry fluids. Appl Therm Eng 2008;28:998-1007. doi:10.1016/j.applthermaleng.2007.06.025. 